\title{
PENGELOLAAN KEBERLANJUTAN EKOSISTEM HUTAN RAWA GAMBUT TERHADAP KEBAKARAN HUTAN DAN LAHAN DI SEMENANJUNG KAMPAR, SUMATERA \\ (Sustainable Management of Peat Swamp Forest Ecosystems Toward Forest and Land Fires in Kampar Peninsula, Sumatera)
}

\author{
Budi Darmawan $^{1 *}$, Yusni Ikhwan Siregar ${ }^{2}$, Sukendi $^{2}$ dan Siti Zahrah ${ }^{3}$ \\ ${ }^{1}$ Program Doktor Program Studi Ilmu Lingkungan, Universitas Riau, \\ Jln. Pattimura No.9 Gobah, Pekanbaru 28131. \\ ${ }^{2}$ Program Studi Ilmu Lingkungan Program Pascasarjana, Universitas Riau, \\ Jln. Pattimura No.9 Gobah, Pekanbaru 28131. \\ ${ }^{3}$ Fakultas Pertanian, Universitas Islam Riau, \\ Jln. Kaharudin Nasution No. 113, Perhentian Marpoyan, Pekanbaru 28284.
}

*Penulis korespondensi. Tel: 08117506113. Email: budi_drw@yahoo.com.

Diterima: 3 Agustus 2015

Disetujui: 11 Januari 2016

\begin{abstract}
Abstrak
Keberadaan ekosistem hutan rawa gambut di Indonesia terus mengalami gangguan dan kerusakan akibat pola pemanfaatan yang tidak bijaksana seperti terjadinya kebakaran hutan dan lahan. Umumnya kebakaran tersebut berasal dari adanya kegiatan manusia seperti penggunaan dan perubahan tutupan lahan. Kawasan Lindung Hutan Rawa Gambut Semenanjung Kampar termasuk salah satu ekosistem hutan rawa gambut terbesar di Pulau Sumatera. Peranan utama dari kawasan ini sebagai penjaga kestabilan lingkungan terhadap kawasan sekitarnya. Tujuan dari penelitian ini adalah untuk mengetahui tingkat dan status serta faktor-faktor kunci yang mempengaruhi keberlanjutan pengelolaan ekosistem hutan rawa gambut terhadap kebakaran hutan dan lahan dengan menggunakan pendekatan Multi-Dimensional Scaling. Mengacu kepada hasil penelitian secara keseluruhan indeks atau status keberlanjutan berada pada kriteria sedang $(45,81 \%)$ atau status cukup berkelanjutan. Secara parsial untuk masing-masing dimensi yang memiliki status cukup berkelanjutan adalah ekonomi, teknologi dan hukum, sedangkan dimensi ekologi dan sosial kurang berkelanjutan sehingga perlu mendapatkan perhatian serius.
\end{abstract}

Kata kunci: gambut, kebakaran, skala, Kampar.

\begin{abstract}
The existence of peat swamp forest ecosystem in Indonesia continues to become distruption and damage which are caused by unwise utilization patterns such as forest and land fires. This happens because of human activities such as the use and change of the land. Protected area of peat swamp forest in Kampar peninsula is one of the largest forest ecosystems in Sumatera. The main function of this area is to maintain environment stability for the surrounding area. This study aims at finding out the level, status and main factors influencing sustainable management of peat swamp forest ecosystems toward forest and land fires by using multi-dimensional scaling approach. Based on the result of the study, it was found that the overall index or continues status was at the mediocre criterion level (45.81\%). Partially, each dimension which has sustainable status includes economy, technology and law, while ecological and social dimensions were not sustainable and need more serious attention.
\end{abstract}

Keywords: peat, fire, scaling, Kampar.

\section{PENDAHULUAN}

Hutan dan lahan gambut merupakan salah satu tipe ekosistem lahan basah (Mitsch and Gosselink, 2000). Luas lahan gambut di Indonesia diperkirakan sekitar 14,95 juta hektar tersebar di pulau Sumatera, Kalimantan dan Papua serta sebagian kecil di Sulawesi (Wahyunto dkk, 2013 ${ }^{\mathrm{a}}$ ). Keberadaan ekosistem hutan dan lahan gambut saat ini semakin terus terancam, karena status eksistensinya mendapat tekanan sangat berat oleh berbagai aktivitas dan kegiatan manusia yang tidak ramah lingkungan (Phillip, 1998; Saharjo, 2007; Lavorel dkk, 2007; Anonim, 2010 ).

Data menunjukkan dari sekitar 14,95 juta hektar lahan gambut diperkirakan 6,66 juta hektar atau 44,6\% telah terdegradasi (Wahyunto dkk, 2013 $3^{\text {a }}$ Wahyunto dkk, 2013 ${ }^{\mathrm{b}}$ ). Tata air yang salah menjadi penyebab utama terjadinya degradasi lahan gambut (Masganti, 2003). Selain itu degradasi lahan 
gambut juga dapat disebabkan oleh kebakaran dan kegiatan penambangan (Masganti dkk, 2014). Lebih parah lagi akibat kebakaran hutan dan gambut akan memberikan kontribusi terhadap perubahan iklim global sebagai akibat pertambahan emisi gas rumah kaca yang dilepaskan ke udara (Masganti dkk, 2014). Padahal fungsi utamanya adalah sebagai sumberdaya keanekaragaman hayati dan tempat penyimpan karbon di alam (Whelan, 1995; Hooijer dkk, 2006; Joosten, 2009). Kebakaran hutan dan lahan gambut sering terjadi saat pembukaan lahan, yang menjadi kontributor emisi gas rumah kaca tertinggi dan sering menyudutkan Indonesia dalam forum internasional tentang lingkungan dan perubahan iklim (Agus dan Subiksa, 2008; Subiksa dkk, 2011). Pembakaran mempercepat proses subsidensi gambut dan degradasi lahan, padahal kecepatan pembentukan gambut untuk hutan primer hanya $3 \mathrm{~mm} /$ tahun (Andriesse, 1988).

Pembakaran juga menyebabkan punahnya mikroorganisme sehingga mengganggu proses dekomposisi dan kimia tanah serta hilangnya berbagai biota atau biodiversitas lainnya (Tan, 1994; Setyaningsih, 2000). Pembakaran memang menghasilkan abu yang mengandung basa-basa, namun tidak cukup untuk menyuplai kebutuhan hara tanaman (Kurnia dkk, 1997; Masganti, 2003). Selain itu kurangnya pengetahuan tentang sistem pertanian dan perkebunan ramah lingkungan menyebabkan masih terjadinya bencana asap setiap tahun dibeberapa provinsi di Indonesia. Asap kebakaran hutan dan lahan gambut dapat menjalar sehingga mengganggu sistem transportasi penerbangan, aktivitas ekonomi dan kesehatan masyarakat seperti infeksi saluran pernapasan akut (ISPA), diare dan gatal-gatal (Sumantri, 2003; Aiken, 2004; Hergoualc'h and Verchot, 2013).

Dampak langsung kebakaran hutan dan lahan gambut bagi manusia adalah kehilangan sumber mata pencaharian masyarakat terutama bagi mereka yang masih menggantungkan hidupnya pada sumber daya alam (berladang, beternak, berburu/menangkap ikan dan sebagainya). Ladang, perkebunan dan lahan pertanian lain yang terbakar akan memusnahkan semua tanaman, yang berarti pada akhirnya produksi pertanian akan ikut terbakar (Adinugroho dkk, 2005). Lahan gambut dikenal sebagai lahan yang rapuh atau rentan dengan perubahan karakteristik yang tidak menguntungkan. Lahan gambut mempunyai manfaat multifungsi yaitu fungsi hidrologi, produksi dan ekologi yang sangat vital bagi kelangsugan hidup manusia dan lingkungan sekitarnya (Masganti, 2003). Oleh karena itu perlu pengelolaan yang khas agar tidak terjadi perubahan karakteristik yang menyebabkan produktivitas lahan menurun, tidak produktif dan terbakar (Masganti dkk, 2014).
Kebijakan pengendalian kebakaran hutan dan lahan gambut di Indonesia belum menyentuh akar permasalahan karena strategi penanggulangan kebakaran masih berfokus pada manajemen pemadaman, sedangkan akar penyebab kebakaran hutan dan lahan gambut semakin kompleks, termasuk sistem pengelolaan sumber daya alam di Indonesia (Chokkalingam dan Suyanto, 2004). Provinsi Riau merupakan salah satu provinsi yang paling rawa terhadap kebakaran hutan dan lahan di Indonesia. Provinsi Riau memiliki pengaruh yang besar terhadap terjadinya polusi asap yang melintas batas negara, di mana pada umumnya kebakaran tersebut berada di lahan gambut (Nurhayati dkk, 2010).

Luas lahan gambut di Provinsi Riau sekitar 3,89 juta hektar dari 6,49 juta hektar total luas lahan gambut di pulau Sumatera. Saat ini diperkirakan lahan gambut yang telah terdegradasi sekitar 2.313.561 hektar atau 59,54\% dari total luas lahan gambut di Provinsi Riau. Sisanya sekitar 1.037.020 hektar dari lahan tersebut dimanfaatkan untuk budidaya tananam seperti kelapa sawit, tanaman pangan dan hortikultura (Wahyunto dkk, 2013ª). Mengacu kepada potensi luas lahan gambut di Provinsi Riau jika tidak dikelola dengan baik maka akan mudah terbakar dan berdampak pada pelepasan karbon ke udara sehingga meningkatkan efek gas rumah kaca.

Kawasan Semenanjung Kampar merupakan salah satu hamparan hutan rawa gambut terluas yang berada di Provinsi Riau. Semenanjung Kampar memiliki ekosistem hutan gambut berada di antara 2 (dua) sungai besar, yaitu Sungai Siak dan Sungai Kampar. Hampir seluruh areal di Semenanjung Kampar merupakan lahan gambut dengan tiga kubah gambut besar (peat dome) sebagai daerah intinya dengan kedalaman gambut tergolong dalam hingga sangat dalam dan beberapa kubah gambut kecil (Qomar dan Jaya, 2010). Tutupan hutan rawa gambut di Semenanjung Kampar pada tahun 1982 mencapai 97\% dari luas total areal 702.129 hektar. Pada tahun 2005 luas tutupan hutan yang ada hanya mencapai $63 \%$ atau telah terjadi deforestasi sebesar 34\% dalam kurun waktu 23 tahun (1982-2005) dari luas keseluruhan kawasan Semenanjung Kampar atau sekitar 260.348 hektar (Rifardi, 2008).

Kawasan Semenanjung Kampar telah ditetapkan oleh Pemerintah Indonesia sebagai salah satu bagian dari area kunci bagi keanekaragaman hayati hutan rawa gambut (Anonim, 2007), dan area penting bagi habitat burung di Pulau Sumatera (Anonim, 2003). Eksistensi hutan gambut Semenanjung Kampar sangat penting dalam melindungi dan melestarikan keanekaragaman hayati, demikian juga dalam mempertahankan fungsi hidrologis dan penjaga stabilitas iklim mikro 
dan makro serta sebagai adaptasi dan mitigasi perubahan iklim global dunia (Anonim, 2010 ). Namun demikian tekanan penggunaan lahan di Semenanjung Kampar oleh berbagai kepentingan telah mengakibatkan semakin menurunkan luasan kawasan berhutan.

Keberadaan ekosistem hutan rawa gambut Semenanjung Kampar mendapatkan tekanan yang cukup berat dan perubahan luasan secara signifikan (Rifardi, 2008; Qomar dan Jaya, 2010). Pembukaan hutan dan lahan gambut untuk pertanian, hutan tanaman industri dan perkebunan yang disertai dengan pembuatan kanal secara besar-besaran serta tidak terkendali diperkirakan akan merubah pola hidrologi secara ekstrim (Siegel dkk, 1995). Apabila perubahan pola hidrologi terus berlanjut maka diperkirakan akan berdampak pada percepatan proses oksidasi dan dekomposisi, khususnya pada kubah gambut (Noor, 2010). Gambut yang mengalami pengeringan berlebihan hingga merusak sifat koloid gambut sehingga menjadi bahan yang mudah terbakar dan meningkatkan resiko kebakaran hutan dan lahan (Hooijer dkk, 2006).

Bila kondisi saat ini (eksisting) terus dibiarkan maka jelas akan mempengaruhi keberlanjutan ekosistem hutan rawa gambut di Semenanjung Kampar. Kondisi eksisting menyebabkan ekosistem hutan rawa gambut Semenanjung Kampar menjadi salah satu fokus dalam penyelamatan keanekaragaman hayati yang saat ini sedang mengalami ancaman kemerosotan akibat degradasi dan deforestasi di Provinsi Riau. Oleh karena itu perlu adanya evaluasi untuk mengetahui tingkat keberlajutannya berdasarkan pendekatan multidimensi agar dapat menentukan langkah yang tepat untuk menjamin keberlanjutan pada masa yang akan datang. Mengacu kepada permasalahan penelitian, maka penelitian ini bertujuan untuk mengetahui tingkat keberlanjutan ekosistem hutan rawa gambut terhadap upaya mengurangi kebakaran hutan dan lahan, berdasarkan 5 dimensi yaitu ekologi, ekonomi, sosial, infrastruktur dan hukum

\section{METODE PENELITIAN}

\section{Waktu dan Lokasi}

Waktu pelaksanaan penelitian dilakukan mulai bulan Januari 2014 hingga Mei 2015. Untuk mewakili kawasan Semenanjung Kampar secara keseluruhan maka lokasi penelitian ditetapkan bertempat di Kecamatan Teluk Meranti, Kabupaten Pelalawan, Provinsi Riau, Indonesia (Gambar 1).

Penetapan lokasi penelitian dilakukan secara sengaja (purposive) dengan alasan bahwa wilayah penelitian masih banyak terdapat hutan dan lahan gambut yang masih tergolong alami dan gambut dalam hingga sangat dalam (> $3 \mathrm{~m})$, banyak terdapat

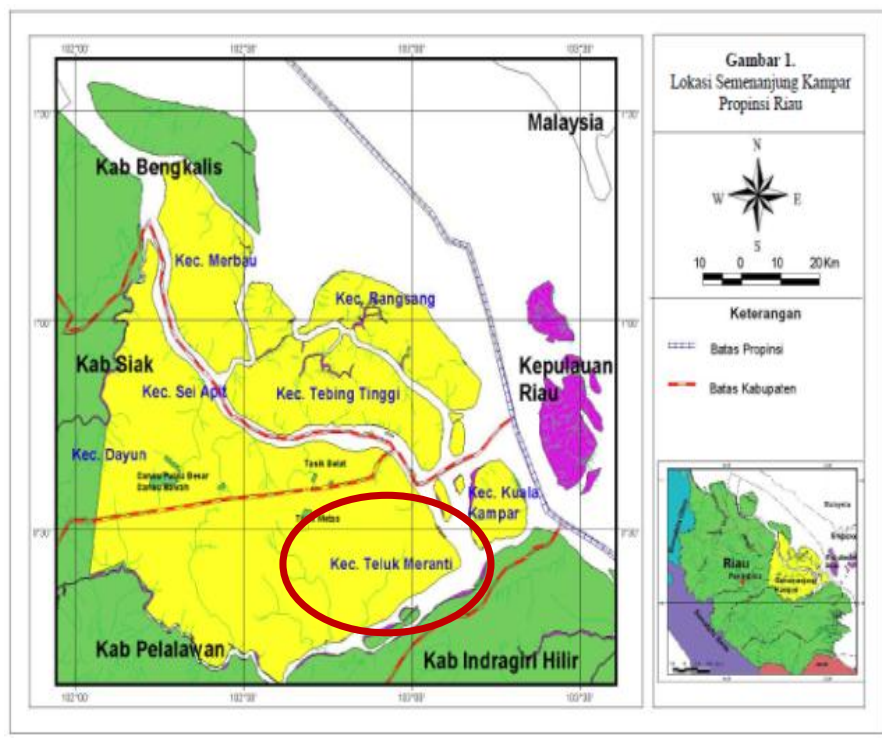

Gambar 1. Lokasi penelitian (Rifardi, 2008).

kegiatan konversi hutan dan lahan gambut untuk pengembangan sektor pertanian, perkebunan dan hutan tanaman industri, tingginya kasus kejadian kebakaran hutan dan lahan gambut, dan berada di zona inti, penyangga dan pemanfaatan kawasan Semenanjung Kampar.

Secara klimatologi keadaan lokasi penelitian tidak dapat dipisahkan dari iklim Provinsi Riau secara keseluruhan dan pada umumnya beriklim tropis, curah hujan bulanan pada umumnya berkisar antara 1.949-2.951 mm/th dengan hari hujan berkisar antara 151-181 hari, jumlah bulan basah 9 bulan dan bulan kering 2-3 bulan. Suhu udara ratarata bulanan berkisar $26,1-27,5^{\circ} \mathrm{C}$ dengan rata-rata tahunan sekitar $26,7^{\circ} \mathrm{C}$ (Anonim, 2014).

\section{Metode Analisis}

Analisis indeks pengelolaan hutan rawa gambut terhadap kebakaran dilakukan melalui analisis keberlanjutan dengan menggunakan metode Multidimensional Scaling (MDS), yaitu pada penelitian ini telah dimodifikasi dari program Rafish $^{T M}$ (Rapid Appraisal for Fisheries) (Kavanagh, 2001; Pitcher and Preikshot, 2001) yang kemudian dinamakan menjadi Model Rap-Gambut. Model Rap-Gambut dilakukan dengan tujuan guna mencari peluang, alternatif dan solusi perbaikanperbaikan berdasarkan pada nilai atribut-atribut sensitif, yaitu dengan cara mengembangkan kedalam 26 atribut kunci yang dikelompokkan ke dalam 5 dimensi, yaitu dimensi ekologi, ekonomi, sosial, teknologi dan hukum.

Dengan menggunakan metode $M D S$, maka posisi titik keberlanjutan dapat divisualisasikan melalui sumbu horizontal dan sumber vertikal. Selanjutnya dengan melakukan proses rotasi, maka posisi titik dapat divisualisasikan pada sumbu horizontal dengan nilai indeks keberlanjutan diberi nilai skor 0\% (buruk) dan 100\% (baik). Jika sistem 
yang dikaji mempunyai nilai indeks keberlanjutan lebih besar atau sama dengan 50\% ( $\geq 50 \%)$, sehingga sistem dikatakan berkelanjutan dan tidak berkelanjutan jika nilai indeks kurang dari $50 \%$ $(<50 \%)$ (Tabel 1).

Nilai indeks keberlanjutan untuk setiap dimensi dapat juga divisualisasikan dalam bentuk diagram layang-layang untuk mempermudah dalam proses perbandingan dan mengetahui titik-titik ketidakberlanjutannya. Analisis ordinasi dengan metode $M D S$ dilakukan melalui beberapa tahapan sebagai berikut: tahap penentuan atribut, tahap penilaian setiap atribut dalam skala ordinal (scoring) berdasarkan kriteria keberlanjutan setiap dimensi, tahap analisis ordinasi untuk menentukan ordinasi dan nilai stress melalui ALSCAL Algorithm, melakukan rotasi untuk menentukan posisi indeks dan status keberlanjutan pada ordinasi bad atau good, dan melakukan analisis sensitivitas, yakni Leverage Analysis dan Monte Carlo Analysis untuk memperhitungkan aspek ketidakpastian (KavanaGh, 2001).

\section{HASIL DAN PEMBAHASAN}

\section{Indeks dan Status Keberlanjutan Dimensi Ekologi}

Analisis indeks dan status keberlanjutan dimensi ekologi menggunakan 5 atribut terpilih, yaitu: tingkat konversi hutan dan lahan gambut, metode bakar ramah lingkungan, pengetahuan fungsi utama hutan rawa gambut, pengetahuan penyebab kebakaran hutan rawa gambut, dan pengetahuan dampak kebakaran hutan rawa gambut. Hasil analisis leverage atribut dimensi ekologi seperti disajikan pada Gambar 2. Hasil analisis leverage atribut dimensi ekologi maka urutan prioritas atribut sensitif tersebut perlu mendapat perhatian lebih atau sangat mempengaruhi pengelolaan keberlanjutan lahan gambut terhadap kebakaran, yaitu pengetahuan tentang fungsi utama lahan gambut. Secara keseluruhan indeks keberlanjutan untuk dimensi ekologi berada pada

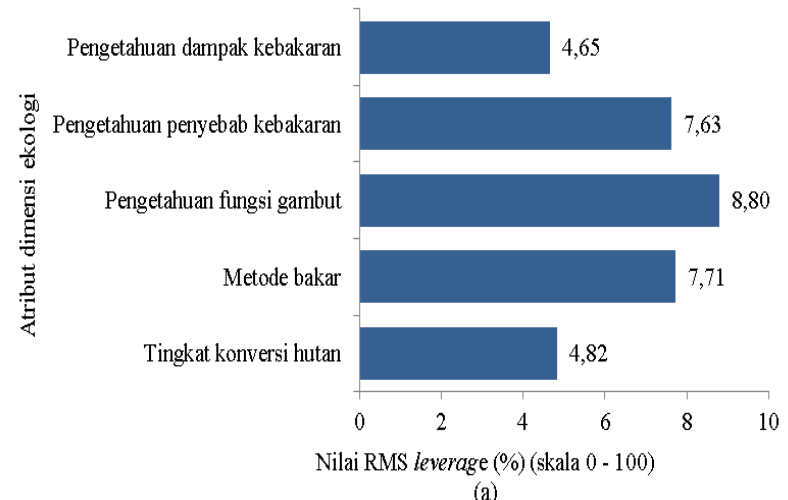

(a) kategori buruk atau tidak berkelanjutan dan berada pada rentang $0-40 \%$ atau secara rata-rata sebesar 33,37\%.

Pengetahuan tentang fungsi utama lahan gambut yang masih rendah disebabkan karena rendahnya tingkat pendidikan masyarakat di lokasi penelitian, yaitu: tidak pernah sekolah $(16,11 \%)$, pendidikan dasar $(40,20 \%)$, pendidikan menengah pertama $(14,77 \%)$, pendidikan menengah atas $(24,16 \%)$, dan sedikit sekali berpendidikan tinggi $(4,70 \%)$. Tingkat pendidikan responden untuk melanjutkan pendidikan ke jenjang yang lebih lanjut relatif masih rendah antara lain karena faktor motivasi dan rendahnya kesadaran orang tua pada saat mereka masih kecil untuk menyekolahkan anakanaknya karena alasan kesulitan ekonomi rumah tangga serta lebih memprioritaskan untuk bekerja membantu orang tua di ladang/bertani, menjadi nelayan, buruh perusahaan perkebunan dan jenisjenis pekerjaan sampingan lainnya.

\section{Indeks dan Status Keberlanjutan Dimensi Ekonomi}

Analisis keberlanjutan indeks dan status dimensi ekonomi menggunakan 5 atribut terpilih, yaitu: penghasilan, pengeluaran, tanggungan, luas kebun, dan pekerjaan. Hasil analisis leverage atribut dimensi ekologi seperti disajikan pada Gambar 3.

Gambar 3 memperlihatkan hasil analisis leverage atribut dimensi ekonomi urutan prioritas atribut yang sangat perlu mendapat perhatian, yaitu persentase luas kebun dan jumlah tanggungan. Secara keseluruhan indeks keberlanjutan untuk

Tabel 1. Nilai indeks, status dan interpretasi keberlanjutan $M D S$.

\begin{tabular}{cc}
\hline Nilai Indeks $(\%)$ & Interpretasi \\
\hline $0-24,99$ & Tidak berkelanjutan \\
$25-49,99$ & Kurang berkelanjutan \\
$50-74,99$ & Cukup berkelanjutan \\
$75-100$ & Sangat berkelanjutan \\
\hline
\end{tabular}

Sumber : Thamrin dkk. (2007).

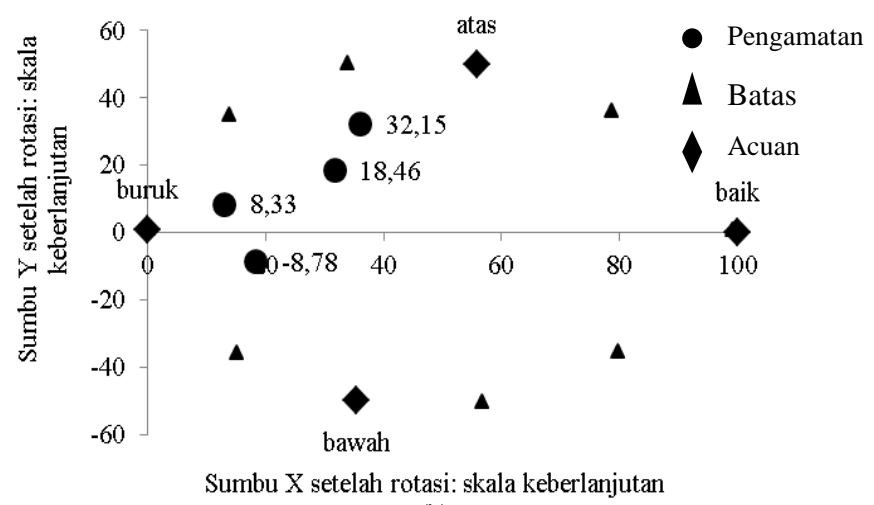

(b)

Gambar 2. (a) Peran masing-masing atribut yang dinyatakan dalam bentuk perubahan RMS, dan (b) indeks dan status keberlanjutan dimensi ekologi. 


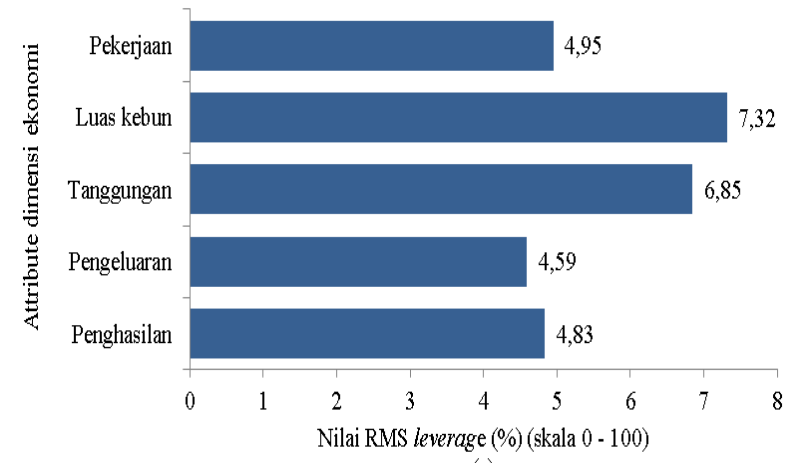

(a)

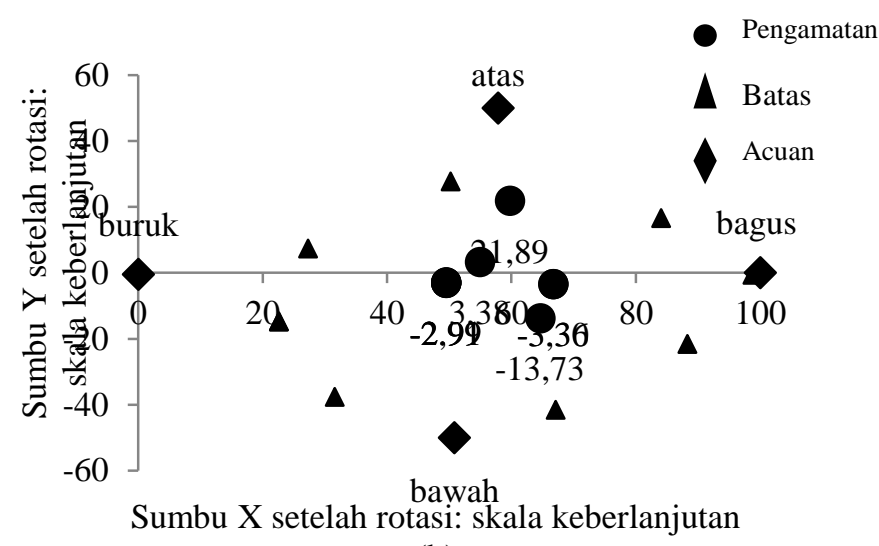

(b)

Gambar 3. (a) Peran masing-masing atribut yang dinyatakan dalam bentuk perubahan RMS, dan (b) indeks dan status keberlanjutan dimensi ekonomi.

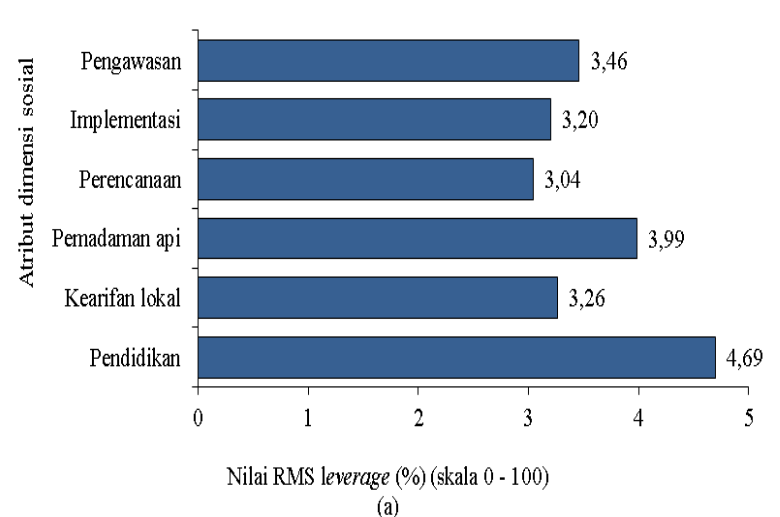

(a)

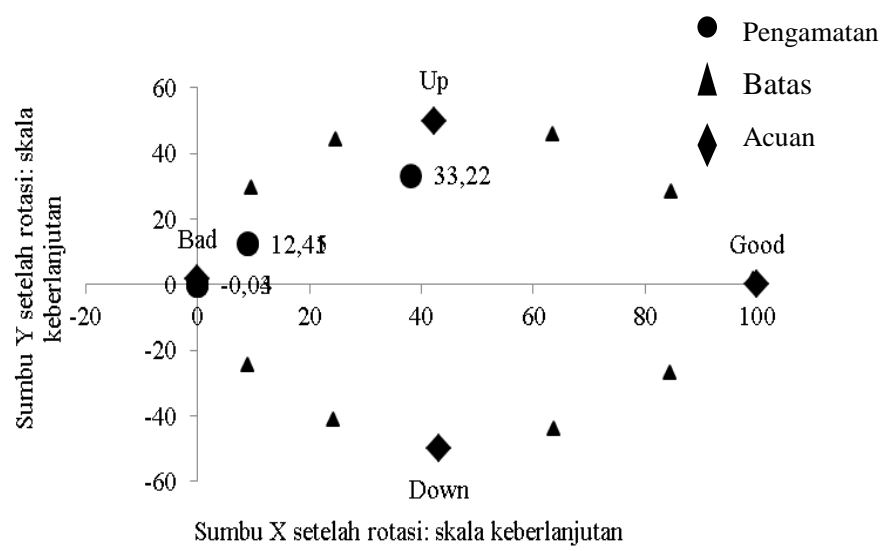

(b)

Gambar 4. (a) Peran masing-masing atribut yang dinyatakan dalam bentuk perubahan $R M S$, dan (b) indeks dan status keberlanjutan dimensi sosial.

dimensi ekonomi berada pada kategori sedang atau cukup berkelanjutan dan berada pada rentang 40$80 \%$ atau secara rata-rata sebesar $56,98 \%$. Mengacu kepada besarnya nilai indeks tersebut mengartikan bahwa dari sisi dimensi ekonomi telah memberikan manfaat yang lebih besar bila dibandingkan dengan dimensi ekologi.

Dimensi ekonomi merupakan salah satu faktor sangat dominan terhadap maraknya kerusakan lingkungan seperti kebakaran dan konversi lahan. Pada dasarnya hampir semua kasus degradasi lahan dan rusaknya ekosistem selalu dipicu dari masalah peningkatan ekonomi. Namun, alternatif ekonomi yang menjadi unsur penting pada program konservasi haruslah mendapat mendukung dari kegiatan konservasi itu sendiri. Sebab, apabila aspek peningkatan ekonomi masyarakat tidak menjadi bagian dari peningkatan kegiatan konservasi, maka kegiatan tersebut justru menjadi permasalahan dan ancaman bagi kawasan yang akan di konservasi.

\section{Indeks dan Status Keberlanjutan Dimensi Sosial}

Analisis keberlanjutan indeks dan status dimensi sosial menggunakan 6 atribut terpilih, yaitu: pendidikan, kearifan lokal, ikut serta dalam proses pemadaman api, ikut serta dalam proses perencanaan pencegahan kebakaran hutan rawa gambut, ikut serta dalam proses implementasi pencegahan kebakaran hutan rawa gambut, dan ikut serta dalam proses pengawasan pencegahan hutan rawa gambut seperti disajikan pada Gambar 4. Hasil analisis leverage atribut dimensi sosial penelitian maka atribut yang paling sensitif dan perlu mendapat perhatian terhadap pengelolaan pencegahan kebakaran, yaitu tingkat pendidikan dan pemadaman api. Secara keseluruhan nilai indeks keberlanjutan untuk dimensi sosial berada pada kategori buruk atau tidak berkelanjutan serta berada pada rentang $0-40 \%$ atau secara rata-rata sebesar $30,61 \%$.

Mulai memudarnya modal sosial dalam hal pengelolaan ekosistem lahan gambut pada saat awal pembukaan lahan juga merupakan faktor pendukung lainnya karena sebagian responden penelitian berupa masyarakat pendatang atau baru menetap di daerah penelitian, yaitu masyarakat yang berasal dari luar daerah yang kemudian bermigrasi untuk mencari penghidupan baru dengan cara membuka hutan rawa gambut untuk sektor kegiatan pertanian dan perkebunan. Selain itu mulai memudarnya nilai kearifan lokal atau aturan-aturan yang sudah diwariskan secara turun-temurun untuk tetap menjaga ekosistem hutan rawa gambut nampaknya sudah mulai berangsur-angsur pudar karena para "tetua" yang ada di dalam masyarakat sudah tiada 

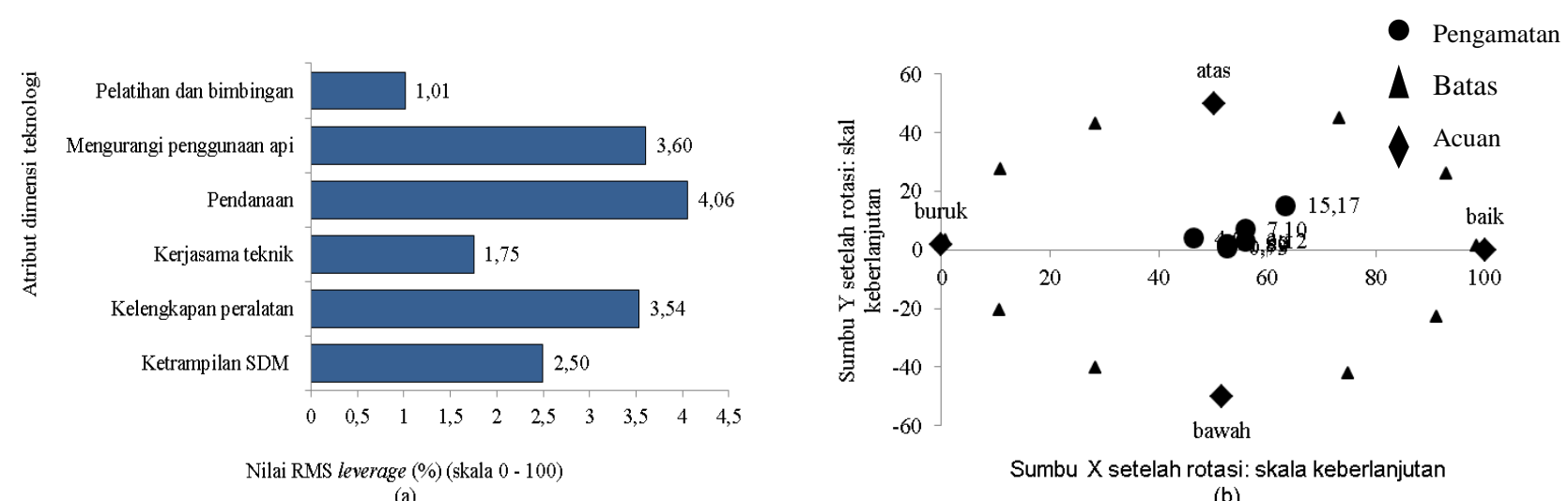

Gambar 5. (a) Peran masing-masing atribut yang dinyatakan dalam bentuk perubahan $R M S$, dan (b) indeks dan status keberlanjutan dimensi teknologi.

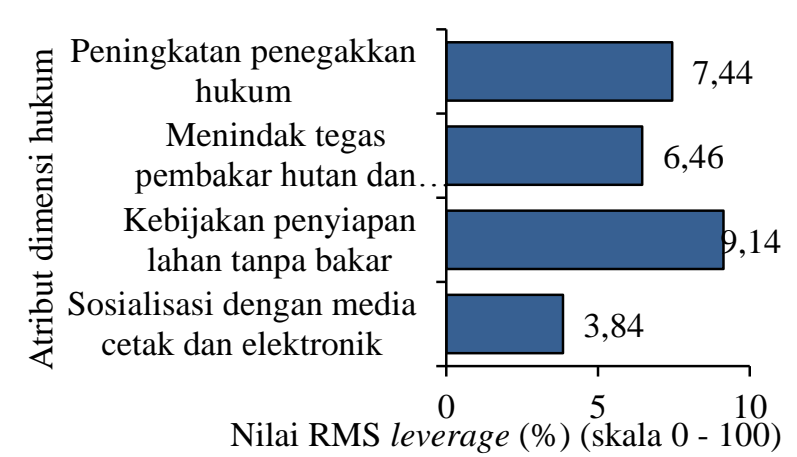

(a)
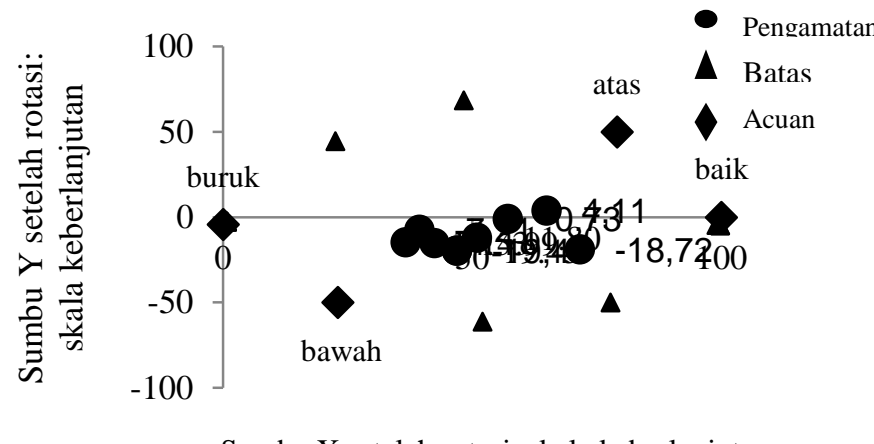

Sumbu X setelah rotasi: skala keberlanjutan

(b)

Gambar 6. (a) Peran masing-masing atribut yang dinyatakan dalam bentuk perubahan $R M S$, dan (b) indeks dan status keberlanjutan dimensi hukum.

atau berkurang intensitasnya untuk selalu mengingatkan peranan penting ekosistem lahan gambut kepada generasi berikutnya.

\section{Indeks dan Status Keberlanjutan Dimensi Teknologi}

Analisis keberlanjutan indeks dan status dimensi teknologi menggunakan 6 atribut terpilih, yaitu: ketrampilan sumber daya manusia, kelengkapan peralatan, kerjasama teknik dengan lembaga donor, pendanaan, pengurangan penggunaan api, dan pelatihan dan bimbingan pencegahan kebakaran seperti disajikan pada Gambar 5. Hasil analisis leverage atribut dimensi teknologi yang paling sensitif dan perlu mendapat perhatian lebih atau mempengaruhi pengelolaan hutan rawa gambut adalah masalah pendanaan, menggurangi penggunaan api, dan kelengkapan peralatan kebakaran. Secara keseluruhan indeks keberlanjutan untuk dimensi teknologi berada pada kategori sedang atau cukup berkelanjutan, yaitu secara rata-rata sebesar $51,99 \%$.

Noor (2010) menyebutkan dalam konteks pencegahan kebakaran, pengelolaan dan konservasi lahan gambut maka pengembangan ilmu dan teknologi mutlak harus dilakukan seperti pendidikan, pertukaran informasi dan kemudahan akses, pelatihan dan lokakarya, perbaikan pengelolaan dengan melibatkan kelompok komunitas lokal, pemecahan masalah isu dan batasan atau ketentuan penggunaan, pengembangan pengelolaan dan opsi restorasi, dan penelitian, pemantauan dan evaluasi.

\section{Indeks dan Status Keberlanjutan Dimensi Hukum}

Analisis keberlanjutan indeks dan status dimensi hukum menggunakan 4 atribut terpilih, yaitu: sosialisasi dengan media cetak dan elektronik, kebijakan penyiapan lahan tanpa bakar, menindak tegas pembakar hutan rawa gambut, peningkatan penegakan hukum seperti disajikan pada Gambar 6 .

Gambar 6 memperlihatkan atribut dimensi hukum yang paling sensitif dan perlu mendapat perhatian lebih atau mempengaruhi pengelolaan hutan rawa gambut terhadap kebakaran adalah kebijakan penyiapan lahan tanpa bakar, peningkatan penegakkan hukum dan menindak tegas pembakar hutan dan lahan. Secara rata-rata keseluruhan indeks keberlanjutan untuk dimensi hukum berada pada kategori sedang atau cukup berkelanjutan, yaitu secara rata-rata sebesar $50,69 \%$.

Penerapan saksi hukum terhadap para pelaku pembakar lahan, baik disegaja maupun tidak disengaja masih belum optimal dan bersifat "tebang pilih". Penegakkan hukum lingkungan, khususnya kebakaran hutan dan lahan gambut seperti menegakkan benang basah. Hukum hanya mampu 
menjaring perusak lingkungan "kelas teri", sedangkan "kelas kakap" masih terus melangsungkan aktivitas perusakan lingkungan. Kerusakan ekosistem lahan gambut di Indonesia terus mengalami peningkatan, sekalipun upaya untuk menekan tingkat kerusakan dan upaya rehabilitasi ekosistem yang rusak telah dilakukan dalam skala yang cukup tinggi dengan menghabiskan anggaran dana dan tenaga yang sangat besar serta waktu yang sangat lama.

Upaya penegakkan hukum oleh aparat untuk memerangi perusakan ekosistem lingkungan, dalam beberapa kasus seperti pembakaran, illegal logging hanya menangkap pelaku pelaksana dilapangan saja. Sementara pihak yang paling berperan, seperti pemilik modal dan jaringannya tidak tersentuh oleh aparat. Dengan demikian kegiatan perusak, pembakar lahan gambut masih terus berlangsung sekalipun sudah banyak pelaku yang diajukan ke pengadilan dan dihukum. Hal ini ditambah lagi dengan vonis ringan yang dijatuhkan kepada pelaku tidak menimbulkan efek jera.

Demikian pula hukum lingkungan hanya bisa menjerat dan menghukum perusak lingkungan miskin dan tidak berdaya, misalnya pada para penebang liar dan masyarakat peladang berpindah dengan luas ladang yang tidak seberapa. Sementara pengusaha "kelas kakap" yang membiayai pengrusakan lahan gambut masih sulit tersentuh oleh hukum, sehingga upaya pengelolaan dan rehabilitasi lingkungan menjadi sia-sia, kerena perusakan lebih cepat dari perbaikan atau konservasi. Apalagi pengrusakan dilakukan dengan menggunakan bantuan alat berat dan peralatan canggih.

Pengelolaan lingkungan hidup seperti ekosistem hutan gambut harus mengacu pada hukum dan kebijakan pengelolaan sumberdaya alam (Noor, 2010). Oleh karena itu perlu ada kemauan politik atau komitmen yang kuat dari pemangku kepentingan dalam hal pengaturan kewenangan pengelolaan dan pemanfaatan sumber daya alam serta ekosistem hutan gambut. Anonim (2006) menyebutkan ada tiga hal yang mendasar yang perlu dipertimbangkan dalam pengelolaan sumber daya alam hutan rawa gambut, yaitu: kerjasama antar lembaga terkait, pendekatan bentang lahan atau tata ruang dan pendekatan berbasis ekosistem.

\section{Indeks dan Status Keberlanjutan Multi Dimensi}

Dari keseluruhan 26 atribut hasil analisis leverage pada masing-masing dimensi ekologi, ekonomi, sosial, teknologi dan hukum maka dapat ditentukan 10 atribut keberlanjutan yang dianggap paling sensitif mempengaruhi status keberlanjutan pengelolaan hutan dan lahan gambut terhadap upaya

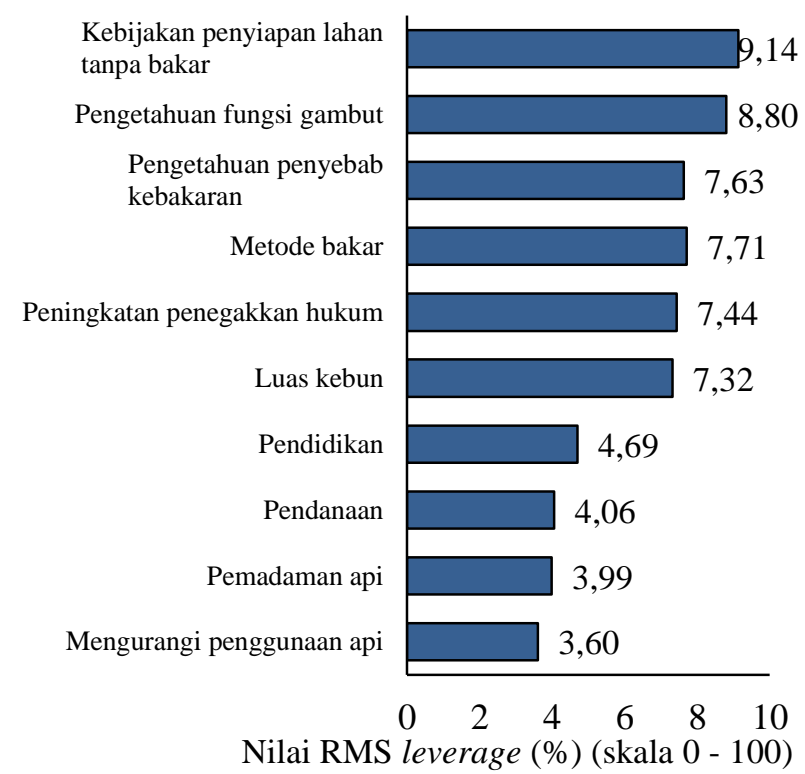

Gambar 7. Urutan atribut-atribut kunci indeks dan status keberlanjutan pengelolaan hutan rawa gambut terhadap kebakaran hutan dan lahan di Semenanjung Kampar.

pencegahan kebakaran sebagaimana disajikan pada Gambar 7.

Gambar 7 memperlihatkan atribut sensitif untuk masing-masing dimensi, yaitu ekologi (peningkatan pengetahuan peranan ekosistem lahan gambut dan pengetahuan penyebab kebakaran lahan gambut), dimensi ekonomi (alokasi atau pembatasan luas kebun dan pendanaan metode tanpa bakar), dimensi sosial (peningkatan pendidikan masyarakat dan ikut serta dalam proses pemadaman api), dimensi teknologi (peningkatan sistem pendanaan pembukaan lahan ramah lingkungan dan mengurangi penggunaan api) dan dimensi hukum (sistem kebijakan penyiapan lahan tanpa bakar dan peningkatan penegakkan hukum).

Prioritas atribut penting pertama dari penelitian ini dapat diketahui bahwa para pengambil kebijakan disarankan melakukan program pembukaan lahan tanpa bakar. Nugroho (1999) menyebutkan pembukaan lahan tanpa bakar adalah dengan cara tebang dan tebas, pilah dan kumpul, lalu pemanfaatan sisa tebangan. Sisa kayu yang biasanya dibakar bisa dimanfaatkan menjadi produk yang bernilai ekonomis. Noor (2010) menyebutkan pembukaan atau penyiapan lahan tanpa bakar memerlukan bantuan herbisida. Semak dan gulma disemprot dengan herbisida dan kemudian dibiarkan untuk dikomposkan dengan bantuan mikroba sehingga perombakan bahan organik dapat dipercepat. Namun demikian cara ini dianggap telah mendorong munculnya emisi gas metan $\left(\mathrm{CH}_{4}\right)$ dari bahan organik yang membusuk secara anaerob. Walaupun demikian, sejauh masih dapat ditoleran 


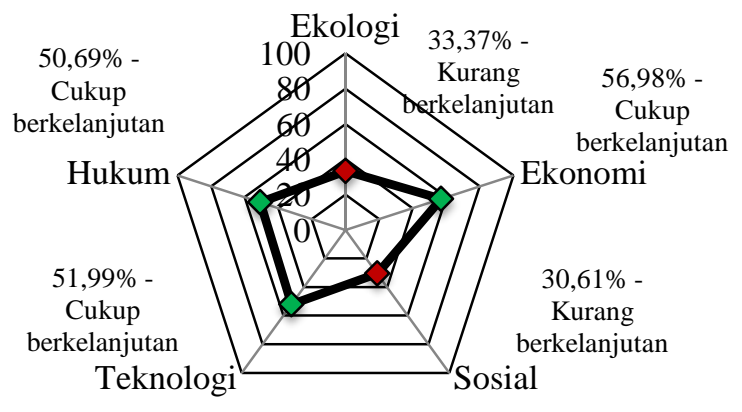

Gambar 8. Diagram layang-layang indeks dan status keberlanjutan pengelolaan hutan rawa gambut terhadap kebakaran hutan dan lahan di Semenanjung Kampar.

dan keuntungan yang diperoleh dari usaha-usaha tersebut secara nyata dapat meningkatkan pendapatan dan kesejahteraan masyarakat.

Atribut sensitif penting kedua yang mempengaruhi indeks dan status keberlanjutan pengelolaan hutan rawa gambut terhadap kebakaran, yaitu masih rendahnya tingkat pengetahuan masyarakat akan peranan (fungsi dan manfaat) ekosistem lahan gambut diduga juga sangat berpengaruh pada indeks dan status eksistensinya. Telah memudarnya kearifan lokal dalam hal pengelolaan hutan rawa gambut pada saat awal pembukaan lahan merupakan faktor pendukung lainnya karena sebagian responden penelitian, yaitu berupa masyarakat pendatang atau baru menetap di daerah penelitian (masyarakat yang berasal dari luar daerah Semenanjung Kampar).

Untuk menggambarkan indeks dan status keberlanjutan pengelolaan hutan rawa gambut terhadap kebakaran secara keseluruhan untuk masing-masing dimensi berdasarkan analisis $M D S$ dapat divisualkan dengan menggunakan diagram layang-layang (kite diagram) seperti disajikan pada Gambar 8. Secara keseluruhan indeks atau tingkat pengelolaan keberlanjutan ekosistem hutan rawa gambut terhadap pencegahan kebakaran berdasarkan pada angka persentase yang dicari yaitu berada pada kriteria sedang atau sebesar $45,81 \%$. Hasil interpretasi berada pada kategori sedang pada pengelolaan keberlanjutan hutan rawa gambut terhadap kebakaran tidak terlepas dari tingginya konversi lahan untuk pengembangan sektor kegiatan pertanian dan perkebunan.

Hutan rawa gambut sebagai ekosistem yang produktif dan sangat berarti bagi penyangga sumber daya alam bagi semua mahluk hidup dan lingkungan sekitar, sehingga perlu tetap dilestarikan. Keberadaan ekosistem hutan rawa gambut dalam mendukung kehidupan sangat strategis. Ekosistem hutan rawa gambut sebagai mendukung fungsi penyangga lingkungan sehingga perlu langkah- langkah strategis untuk menekan tingkat kerusakan dan melestarikan akibat degradasi/kerusakan dan kebakaran hutan dan lahan gambut (Rieley dan Page, 2003).

Untuk mempertahankan dan meningkatkan status keberlanjutan pengelolaan hutan rawan gambut terhadap kebakaran kedepan, maka sebaiknyan perlu dilakukan intervensi (perbaikan) terhadap atribut yang sangat berpengaruh dengan cara mengacu kepada indikator pembangunan berkelanjutan sebagaimana yang telah ditargetkan oleh pemerintah melalui mekanisme REDD+ (Anonim, 2012; Venter dan Koh, 2012) dan pengelolaan hutan dan lahan gambut berkelanjutan (Ritung dan Wahyunto, 2003; Wahyunto dan Mulyani, 2011) yang disesuaikan dengan rencana pengembangan dan pembangunan wilayah.

Hutan rawa gambut Semenanjung Kampar memiliki kepentingan nyata untuk pengembangan sosial-ekonomi dan mendukung kehidupan masyarakat. Jika dikelola dengan baik atau dipertahankan sifat alamiahnya maka hutan rawa gambut Semenanjung Kampar akan mampu memberikan berbagai jasa lingkungan bagi manusia maupun mahluk hidup lain di atas/sekitarnya. Kerusakan ekosistem lahan gambut dapat ditekan dengan cara mengelola berbagai atribut sensitif yang menjadi penyebabnya. Selama ini kerusakan yang terjadi lebih disebabkan oleh banyak faktor manusia bila dibandingkan faktor alami. Oleh karena itu, implikasi penemuan penelitian ini sebagai upaya untuk mengurangi atau menekan kejadian kebakaran dengan cara melakukan pengelolaan ekosistem hutan rawa gambut secara terpadu dan berkelanjutan berbasis ekosistem dan partisipasi semua stakeholders terkait.

\section{Uji Sensitivitas Indeks dan Status Keberlanjutan}

Untuk menggambarkan keabsahan analisis $M D S$ maka dilakukan dengan menggunakan uji statistik, yaitu dengan cara membandingkan nilai $S$ Stress terhadap nilai Root Mean Square (RMS) dari masing-masing dimensi pengelolaan keberlanjutan hutan rawa gambut terhadap kebakaran seperti disajikan pada Tabel 1.

Tabel 1 memperlihatkan hasil uji statistik $M D S$ sudah dapat memenuhi Goodness of Fit dengan selang kepercayaan $95 \%$, nilai $S$-Stress lebih kecil dari $25 \%$. Nilai $R M S$ cukup tinggi atau mendekati angka $100 \%$. Hasil analisis uji statistik sudah cukup menerangkan bahwa seluruh atribut sensitif setiap dimensi cukup baik untuk menerangkan indeks keberlanjutan pengelolaan hutan rawa gambut terhadap kebakaran di Semenanjung Kampar. Untuk mengetahui aspek ketidakpastian hasil analisis MDS 
Tabel 1. Nilai $S$-Stress dan $R M S$ masing-masing dimensi.

\begin{tabular}{lccc}
\hline \multicolumn{1}{c}{ Dimensi } & S-Stress $(\%)$ & RMS $(\%)$ & Iterasi\# \\
\hline Ekologi & 16,37 & 91,92 & 25 \\
Ekonomi & 19,96 & 87,56 & 25 \\
Sosial & 14,12 & 94,18 & 25 \\
Teknologi & 22,53 & 90,55 & 25 \\
Hukum & 22,67 & 92,12 & 25 \\
\hline
\end{tabular}

Sumber : Hasil analisis.

maka digunakan analisis sensitivitas Monte Carlo seperti disajikan pada Tabel 2.

Tabel 2 memperlihatkan hasil uji analisis sensitivitas maka selisih antara hasil analisis MDS dengan analisis Monte Carlo tidak jauh berbeda, sehingga dapat digunakan untuk menggambarkan kondisi daerah penelitian. Metode Rap-Gambut yang dimodifikasikan dari Rapfish hasil penelitian ini dapat diterapkan dalam merumuskan kebijakan dan program pengelolaan hutan rawa gambut terhadap kebakaran di Semenanjung Kampar.

\section{KESIMPULAN}

Hutan rawa gambut diketahui sebagai sumber daya alam yang rapuh atau rentan dengan perubahan karakteristik yang tidak ramah lingkungan. Oleh karena itu perlu pengelolaan yang spesifik agar tidak terjadi perubahan karakteristik yang menyebabkan peranannya semakin menurun, apalagi terjadi kerusakan yang sangat parah (kebakaran). Hasil evaluasi terhadap 5 dimensi indeks dan status keberlanjutan pengelolaan hutan rawa gambut terhadap kebakaran di Semenanjung Kampar telah menyebabkan dimensi ekologi dan sosial kurang berkelanjutan. Tingkat keberlanjutan kedua dimensi tersebut lebih disebabkan rendahnya tingkat pengetahuan akan peranan (fungsi dan manfaat) ekosistem hutan rawa gambut karena masih menggunakan metode bakar saat pembukaan lahan sebab dianggap cara murah dan mudah. Selain itu masih lemahnya penegakkan hukum yang dilakukan oleh aparat terkait mengakibatkan masih leluasanya oknum masyarakat dan perusahaan melakukan konversi lahan dengan cara membakar.

Untuk menjamin keberlanjutan peranan ekosistem hutan rawa gambut di Semenanjung Kampar maka stakeholders terkait perlu melakukan intervensi kebijakan khusus guna mengurangi kebakaran dengan cara penerapan inovasi teknologi atau alternatif program pembukaan lahan tanpa bakar, subsidi atau pendanaan teknologi pertanian/ perkebunan ramah lingkungan, dan penguatan penegakkan hukum terhadap para pelaku pembakar lahan. Ketiadaan kelembagaan yang berfungsi untuk
Tabel 2. Hasil analisis Monte Carlo dan MDS pada selang kepercayaan $95 \%$.

\begin{tabular}{lccc}
\hline \multicolumn{1}{c}{ Dimensi } & MDS & Monte & Selisih \\
\hline Ekologi & 33,37 & 34.63 & 1,26 \\
Ekonomi & 56,98 & 56,99 & 0,01 \\
Sosial & 30,61 & 31,95 & 1,34 \\
Teknologi & 51,99 & 51,95 & 0,04 \\
Hukum & 50,69 & 50,47 & 0,22 \\
\hline
\end{tabular}

Sumber : Hasil analisis.

mengatur pengelolaan kawasan Semenanjung Kampar secara terpadu menyebabkan ketidapastian yang cukup besar mengenai masa depannya. Untuk itu diperlukan upaya terpadu dan kemauan politik yang kuat oleh pemangku kepentingan untuk mengelola eksistensi kawasan Semenanjung Kampar.

\section{DAFTAR PUSTAKA}

Adinugroho, W.C., Suryadiputra, I.N.N., Saharjo, B.H., dan Siboro, L., 2005. Panduan Pengendalian Kebakaran Hutan dan Lahan Gambut: Wetlands International - IP, Bogor.

Agus, F. dan Subiksa, I.G.M., 2008. Lahan Gambut: Potensi Untuk Pertanian dan Aspek Lingkungan. Balai Penelitian Tanah, Bogor. 36 hal.

Aiken, S.R., 2004. Runaway Fires, Smoke-Haze Pollution, and Un-natural Disasters in Indonesia. The Geographical Review, 94(1):55-79.

Andriesse, J.P., 1988. Nature and Management of Tropical Peat Soils. Soil Resources Management \& Conservation Service. FAO Land and Water Development Divisions. FAO, Rome. 165 pp.

Anonim, 2003. Important Bird Areas in Asia: Key Sites for Conservation. Birdlife International (Birdlife Conservation Series No. 13). Cambridge.

Anonim, 2006. Strategi dan Rencana Tindak Nasional Pengelolaan Lahan Gambut Berkelanjutan. Kelompok Kerja Pengelolaan Lahan Gambut Nasional. Jakarta.

Anonim, 2007. Priority Sites for Conservation in Sumatra: Key Biodiversity Area. Departemen Kehutanan Republik Indonesia, Jakarta.

Anonim, 2010a. Profil Ekosistem Gambut di Indonesia. Kementerian Lingkungan Hidup Republik Indonesia. Jakarta.

Anonim, 2010 . Strategi Pengelolaan Ekosistem Rawa Gambut. Untuk Penurunan Emisi Gas Rumah Kaca (GRK) dalam Rangka Adaptasi dan Mitigasi Perubahan Iklim. Seminar dan 
Lokakarya Revitalisasi dan Penguatan Jejaring Kerjasama Pusat Penelitian Lingkungan Hidup Lembaga Penelitian Universitas Riau, Pekanbaru.

Anonim, 2012. Strategi Nasional REDD+: MRV Sebagai Instrument Pengukuran Keberhasilan Pelaksanaan.

Anonim, 2014. Laporan Klimatologi Tahun 2014. Badan Meteorologi Klimatologi dan Geofisika. Pekanbaru.

Chokkalingam, G.U., dan Suyanto, S., 2004. Kebakaran, Mata Pencaharian, dan Kerusakan Lingkungan pada Lahan Basah di Indonesia: Lingkaran yang Tiada Berujung Pangkal. CIFOR/ICRAF. Fire Brief 4: 4 hal.

Hergoualc'h, K., dan Verchot, L.V., 2013. Greenhouse Gas Emission Factors for Land Use and Land-Use Change In Southeast Asian Peatlands. Mitigation and Adaptation Strategies for Global Change. Bogor.

Hooijer, A., Silvius, M., Wösten, H. and Page, S., 2006. Peat- $\mathrm{CO}_{2}$, Assessment of $\mathrm{CO}_{2}$ Emissions from Drained Peatlands in SE Asia. Delft Hydraulics report Q3943.

Joosten, H., 2009. Peatland Status and Drainage Related Emissions in All Countries of The World. The Global Peatland $\mathrm{CO}_{2}$ Picture. Wetlands International. Bangkok.

Kavanagh, P., 2001. Rapid Appraisal of Fisheries (RAPFISH) Project. University of British Columbia, Fisheries Centre.

Kurnia, U., Sinukaban, N., Suratmo, F.G., Pawitan, H., dan Suwardjo, H., 1997. Pengaruh Teknik Rehabilitasi Lahan Terhadap Produktivitas Tanah dan Kehilangan Hara. J. Tanah dan Iklim, 15:10-18.

Lavorel, S., Flannigan, M,D., Lambin, E.F., dan Scholes, M.C., 2007. Vulnerability of Land Systems to Fire: Interactions among Humans, Climate, the Atmosphere, and Ecosystems. Mitig. Adapt. Strat. Glob Change, 12:33-53.

Masganti, 2003. Kajian Upaya Meningkatkan Daya Penyediaan Fosfat dalam Gambut Oligotrofik. Disertasi. Program Pascasarjana Universitas Gadjah Mada, Yogyakarta. 355 hal.

Masganti, Wahyunto., Ai Dariah., Nurhayati., dan Yusuf, R., 2014. Karakteristik dan Potensi Pemanfaatan Lahan Gambut Terdegradasi di Provinsi Riau. J. Sumberdaya Lahan, 8:47-54.

Mitsch, W.J. dan Gosselink, J.M., 2000. Wetlands. Third Edition. John Wiley \& Sons, Inc.

Noor, M., 2010. Lahan Gambut. Pengembangan, Konservasi, dan Perubahan Iklim. Gadjah Mada University Press. Yogyakarta.
Nugroho, B., 1999. Hutan Kita Dibakar. Skephi dan Institut Studi Arus Informasi. Midas Surya Grafindo. Jakarta.

Nurhayati, A.D., Aryanti, E., dan Saharjo, B.H., 2010. Kandungan Emisi Gas Rumah Kaca pada Kebakaran Hutan Rawa Gambut di Pelalawan Riau. J. Ilmu Pertanian Indonesia, 15(2):78-82.

Phillips, V.D., 1998. Peatswamp Ecology and Sustainable Development in Borneo. Biodiversity and Conservation, 7: 651-671.

Pitcher, T.J., dan Preikshot, D.B., 2001. Rapfish: A Rapid Appraisal Technique to Evaluate the Sustainability Status of Fisheries. Fisheries Research, 49(3):255-270.

Qomar, N., dan Jaya, Y.V., 2010. Deforestasi dan Penggunaan Lahan Lansekap Semenanjung Kampar, Riau. Seminar dan Lokakarya Revitalisasi dan Penguatan Jejaring Kerjasama Pusat Penelitian Lingkungan Hidup, Pekanbaru 19-20 November 2010.

Rifardi, 2008. Degradasi Ekologi Sumberdaya Hutan dan Lahan (Studi Kasus Hutan Rawa Gambut Semenanjung Kampar Propinsi Riau). Jurnal Bumi Lestari, 8(2):145-154.

Rieley, J.O. 2003. Strategies for Implementing Sustainable Management of Peatland in Borneo. Strapeat-UNINOT. Wageningen.

Rieley, J.O., dan Page, S.E., 2005. Wise Use of Tropical Peatlands: Focus on Southeast Asia. ALTERRA-Wageningen University and Research Centre and the EU INCOSTRAPEAT and RESTORPEAT Partnerships, Wageningen.

Ritung S, dan Wahyunto, 2003. Kandungan Karbon Tanah Gambut di Pulau Sumatera. Workshop on Wise Use and Sustainable Peatlands Management Practices October 13-14. Bogor.

Saharjo, B.H., 2007. Shifting Cultivation in Peatlands. Mitig Adapt Strat Glob Change 12:135-146.

Setyaningsih, R., 2000. Dinamika Populasi Mikroorganisme yang Berperan dalam Kesuburan di Beberapa Jenis Tanah akibat Perlakukan Paraquat. Tesis. Program Pascasarjana Universitas Gajah Mada, Yogyakarta. 71 hal.

Siegel, D.I, Reeve, A.S., Glaser, P.H., dan Romanowicz, E.A., 1995. Climate-Driver Flushing of Pore Water in Peatlands. Nature 374:531-533.

Subiksa, I.G.M, Hartatik, W., dan Agus, F., 2011. Pengelolaan Lahan Gambut secara Berkelanjutan. Balai Penelitian Tanah, Bogor. 16 hal.

Sumantri, 2003. Prinsip Pencegahan Kebakaran Hutan. IPB Press. Bogor. 
Tan, K.H., 1994. Environmental Soil Science. Marcel Dekker Inc., New York. p 304.

Venter, O. dan Koh, L.P., 2012. Reducing Emissions from Deforestation and Forest Degradation (REDD+): Game Changer or Just Another Quick Fix?. Ann. N.Y. Acad. Sci., 1249:137150.

Wahyunto, dan Mulyani, A., 2011. Pengelolaan Lahan Gambut Berkelanjutan. Balai Besar Litbang Sumberdaya Lahan Pertanian. Badan Penelitian dan Pengembangan Pertanian Kementerian Pertanian. Bogor.
Wahyunto, Ritung, S., Nugroho, K., Sulaiman, Y., Hikmarullah., Tafakresnanto, C., Suparto, dan Sukarman, 2013 ${ }^{\mathrm{a}}$. Peta Arahan lahan Gambut Terdegradasi di Pulau Sumatera Skala 1:250.000. Badan Litbang Pertanian, Kementerian Pertanian. Bogor. 27 hal.

Wahyunto., Dariah, A., Pitono, D., dan Sarwani, M., $2013^{\text {b }}$. Prospek Pemanfaatan Lahan Gambut Untuk Perkebunan Kelapa Sawit di Indonesia. Perspektif, 12(1):11-12.

Whelan, R.J., 1995. The Ecology of Fire. Cambridge University Press, New York. 343 p. 